\title{
Introduction: (Mis)Leading
}

\author{
Miriam Janechek \& Danielle R. Kennedy, editors
}

This special issue of the Iowa Journal of Cultural Studies marries together two of the most important aspects of graduate student development - conference participation and publication. To celebrate the high standard of scholarship produced by graduate students at not only the University of Iowa but also schools around the nation, the Journal created a special issue specifically for scholars who present at the Craft Critique Culture Conference. This conference, hosted by the English department graduate students at the University of Iowa, offers graduate students the unique opportunity to present research as well as creative writing and art. This issue is the first time the three have come together, and it is an exemplar of the high quality work graduate students generate.

The Craft Critique Culture Conference is in its fifteenth year as a graduate student-run organization. It has a long tradition of creative, innovative conference themes as well as attracting brilliant senior scholars to participate as keynote speakers. The 2014 CCC collected together presenters under the theme "Mis-Leading" and brought Dr. Marah Gubar to Iowa. Dr. Gubar, herself an enthusiastic supporter of graduate student work, offered a unique keynote address that worked through the complexities and rewards of forging new paths in scholarship, a path she called the "third way." Her talk encouraged young scholars to trust their instincts about the texts they work with and their personal reactions to scholarship they read. It is in those reactions, she argued, that one can find something different and new to 
bring to the conversation. In the spirit of her talk, Journal editors took to the conference panels to identify strong papers that create new ways in scholarship.

Following the theme of the conference, the articles collected here each illustrate a new way of considering literature, historical events, or contemporary culture that illuminate complexities, demonstrate misleading assumptions, and engage "third ways." For example, Justin Cosner engages with the misleading representations of religious faith in Charles Brockden-Brown's Wieland, arguing that the text illuminates a larger critique of the impulse to assert religious certainty and totalizing rational understanding of the world in nineteenth-century America. Turning to more contemporary literature, Faith Avery's discussion of Toni Morrison's Tar Baby argues for the misleading nature of selfishness throughout the novel. Avery argues that Morrison's readers are asked to question whether selfishness in the name of individuality is akin to "selling out" in the case of the novel's protagonist, Jadine. Avery points out how this misleading contradiction allows Morrison to direct ethical examination in the novel toward issues of racial and cultural re-appropriation. Together, these articles present the importance of questioning typical or mainstream critical narratives as each demonstrates the way scholarship can redirected from misleading understandings of both literature and culture.

Sitting comfortably in the center of this scholarship is Aimee Valentine's autobiographical cartoon on growing up in Kansas, finding a political voice in college, and coming to terms with the misleading narratives of win-or-lose political rhetoric. In her cartoon Blue State of Mind, Valentine explores her own forays into political campaigning, giving her audience an intimate look at her personal growth and complex understanding of American politics in our contemporary moment. In this intensely personal narrative, Valentine exposes the ways in which we are capable of misleading ourselves and the struggles we experience coming to terms with the difficulties of seemingly simple political rhetoric. Her aesthetically beautiful cartoon celebrates the triad of Craft Critique Culture.

Approaching more contemporary literary and cultural questions, the articles following Valentine's autobiographical cartoon speak to literature's complex and misleading influence in our modern moment. Chelsea Burk's article, "'We are alive': (Mis)Reading Joy Harjo's Noni Daylight as a Yellow Woman,” discusses Leslie Marmon Silko's influence on Joy Harjo's poetry. In particular, Burk analyzes two common figures in each author's work, Noni Daylight and the Yellow Woman, to illuminate Harjo and Silko's contributions to feminist storytelling. Taking on questions of storytelling in film and media studies, Ben Kirbach delves into the strange world of YouTube reviews by examining RedLetterMedia's absurdist review of Star Wars: Episode I-The Phantom Menace. The narrator of the film, Harry S. Plinkett, is depicted as psychotic and Kirbach argues that Plinkett's psychosis serves two purposes: it both provides catharsis to those who were disappointed by the film as well as demonstrating the extent to which criticism is generative, not 
merely derivative. Finally, approaching critique in political discourse, Volha Kananovich provides a critical discourse analysis of the Russian punk band Pussy Riot's "punk prayer" and the expert report about it given during the 2012 court case. She argues that while both the prayer and the report seems to present similar aims, it is only through careful analysis that we can fully appreciate how the band's prayer diverge from the official narrative given regarding the band's cultural critique.

We as editors are proud of both the variety and quality of the scholarship presented here, and we have relished the opportunity to work closely with these scholars over the past several months. At a time when academic life feels increasingly precarious, our passionate dedication to research and writing serves as a stabilizing influence. But as graduate education and academic life continues to change, we must continue to look for "third ways" of learning and listening, always seeking to change both our minds and our disciplines. 